\title{
Urgensi Pembelajaran Menerjemah Arab-Indonesia Pada Perguruan Tinggi Agama Islam Di Indonesia
}

\author{
Umi Hanifah \\ Universitas islam Negeri Sunan Ampel \\ E-mail: umihanifah78@yahoo.com
}

\begin{abstract}
The progress of a nation can be achieved through translation activities. The rapid development of science began with the implementation of translation institutions which later became educational institutions. In Indonesia, translation activities from Arabic to Indonesian are focused on religious texts, ranging from the Holy Qur'an, Hadith, and Interpretation to books on da'wah, morals, and Islamic thought books. There are several problems that are often faced by Indonesian translators, including regarding difficult translation activities, substantial differences between Arabic and Indonesian, the lack of mastery of the translator towards the recipient's language, resulting in symptoms of interference, and lack of mastery of the translator's theory of translation. For this reason, translating courses need to be taught at Islamic universities in Indonesia. Learning to translate in Indonesia aims to equip students with knowledge about the theory of translation and to provide students with experience in translating various types of texts, such as religious, scientific, literary, economic, and cultural texts with various levels of difficulty. To be able to achieve this goal, the translator lecturer must have theoretical qualifications, experience, and master the source language and language of the recipient as well as well as master the culture of both languages namely Arabic-Indonesian.
\end{abstract}

Keyword: learning, translating Arabic-Indonesia, Islamic Higher Education in Indonesia.

\begin{abstract}
Abstrak: Kemajuan suatu bangsa dapat dicapai melalui kegiatan penerjemahan. Pesatnya perkembangan ilmu pengetahuan dimulai dengan implementasi lembaga penerjemahan yang kemudian menjadi lembaga pendidikan. Di Indonesia, kegiatan penerjemahan dari bahasa Arab e bahasa Indonesia difokuskkan pada teks-teks agama, mulai dari Al-Qur'an, Hadits, dan interpretasi hingga buku-buku tentang dakwah, moral, dan bukku pemikiran Islam. Ada beberapa masalah yang sering dihadapi oleh para penerjemah Indonesia, termasuk mengenai kegiatan terjemahan yang sulit, perbedaan substansial antara bahasa Arab dan bahasa Indonesia, urangnya penguasaan penerjemah terhadap bahasa penerima mengaibatkan gejala gangguan, kurangnya penguasaan penerjemah, teori penerjemahan. Untuk alasan ini, kursus penerjemahan perlu diajarkan di universitas-universitas Islam di Indonesia. Belajar menerjemahkan di Indonesia bertujuan untuk membekali siswa dengan pengetahuan teori penerjemahan dan untuk memberikan siswa pengalaman dalam menerjemahkan berbagai jenis teks, seperti teks agama, ilmiah, sastra, ekonomi, dan budaya dengan berbagai tingkat kesulitan. Untu dapat mencapai tujuan ini, dosen penerjemah harus memiliki kualifikasi teoritis, pengalaman dan menguasai bahasa sumber dan bahasa penerima serta menguasai budaya kedua bahasa yaitu Arab-Indonesia.
\end{abstract}

Kata kunci: Pembelajaran, menerjemah Arab-Indonesia, Perguruan Tinggi Agama Islam di Indonesia

\section{A. Pendahuluan}


Kebutuhan masyarakat terhadap tenaga penerjemah yang profesional terus meningkat. Untuk memenuhi kebutuhan tersebut, diselenggarakanlah lembaga pendidikan penerjemah secara formal di bawah fakultas sastra atau fakultas lain yang relevan, termasuk fakultas pendidikan bahasa Arab. Lembaga tersebut berupaya mengajarkan ihwal menerjemah melalui teori dan praktik.

Pada lembaga yang tidak memiliki Jurusan khusus menerjemah, seperti halnya Fakultas Ilmu Tarbiyah dan Keguruan dan Fakultas Adab PTAIN, bidang menerjemah merupakan salah satu mata kuliah yang diajarkan kepada para mahasiswa. Penempatan mata kuliah ini didasarkan atas kedudukannya yang sangat penting dalam menunjang kegiatan perkuliahan lainnya. Di samping itu, mata kuliah menerjemah juga dapat memberikan bekal pada mahasiswa dengan prinsip-prinsip dasar penerjemahan yang akan dikembangkan lebih lanjut ketika mereka menekuni bidang tersebut. Sebagai contoh, di Jurusan PBA Fakultas Ilmu Tarbiyah dan Keguruan UIN Sunan Ampel, mata kuliah Terjemah termasuk Mata Kuliah Keahlian Alternatif (MKKA), yang tujuan utamanya adalah mencetak guru bahasa Arab yang ahli dibidang menerjemah. Sehingga setelah lulus, diharapkan mereka bisa menjadi seorang guru bahasa Arab professional sekaligus seorang penerjemah handal. ${ }^{1}$

Kegiatan menerjemah membutuhkan keterampilan berbahasa yang memadai dan juga seni dalam merangkai kalimat, sehingga hasil terjemahan terasa seperti tulisan aslinya. Untuk bisa memiliki kompetensi dalam menerjemahkan teks Arab ke dalam bahasa Indonesia atau sebaliknya, seorang penerjemah harus memahami teori tentang penerjemahan.

diharapkan artikel singkat ini bermanfaat bagi para pengajar dan pembelajar bahasa Arab, baik di Perguruan Tinggi Agama Islam Negeri Maupun Swasta serta bagi masyarakat luas yang memiliki minat dalam bidang menerjemah.

B. Peran Penerjemahan dalam Memajukan Ilmu Pengetahuan dan Peradaban Umat Manusia

${ }^{1}$ Kurikulum KKNI Prodi PBA UIN Sunan Ampel, 2018. 


\section{URGENSI PEMBELAJARAN MENERJEMAH} ARAB-INDONESIA

Sebuah kebudayaan tidak lahir dari kekosongan. Suatu kebudayaan selalu didahului oleh kebudayaan-kebudayaan lain yang merupakan unsur pembentuknya. Kebudayaan suatu bangsa merupakan ikhtisar dari kebudayaan sebelumnya atau seleksi dari berbagai kebudayaan lain. Dengan begitu kebudayaan dapat dianggap sebagai proses memberi dan menerima. ${ }^{2}$

Proses terjadinya dan berkembangnya kebudayaan tersebut melalui berbagai sarana, di antaranya adalah penerjemahan. Dalam catatan sejarah ditegaskan bahwa peradaban Islam pada awalnya berkembang melalui penerjemahan karya-karya lama Yunani, Persia, India, dan Mesir dalam bidang ilmu eksakta dan kedokteran. Kegiatan penerjemahan ini dimulai pada masa pemerintahan Khalifah Abu Ja'far al-Mansur (137-159 H./754-775 M.), salah satu khalifah dari Dinasti Abbasiah. Upaya penerjemahan yang dimulai oleh khalifah Abu Ja'far tersebut berhasil dan mencapai puncaknya pada masa Khalifah al-Ma'mun sehingga mengantarkan umat Islam ke masa keemasan. ${ }^{3}$

Pada gilirannya bangsa Eropa menyerap dan menyeleksi kebudayaan juga melalui kegiatan penerjemahan. Menurut Newmark, ${ }^{4}$ Sekolah Toledo-lah yang telah berjasa mentransfer kebudayaan Arab dan Yunani melalui kegiatan penerjemahan.

Dari catatan sejarah tersebut, Zdenek Zalmann ${ }^{5}$ menyimpulkan bahwa hutang budi bangsa Arab terhadap bangsa Yunani dan Romawi (Eropa) akhirnya terbayar pula dengan hutang budi bangsa Eropa terhadap bangsa Arab hingga mereka meraih masa pencerahan. Sejak abad ke-12 pusat-pusat penerjemahan berdiri di Spanyol dan Italia. Jika bangsa Arab menjadikan Baghdad sebagai pusat utama kegiatan penerjemahan karya-karya bangsa Romawi dan Yunani, maka bangsa Eropa menjadikan Toledo sebagai pusat penerjemahan karya-karya bangsa Arab.

Menurut sejarah, kemajuan bangsa Jepang juga diraih di antaranya melalui kegiatan penerjemahan pada masa pemerintahan Meiji. Pesatnya

\footnotetext{
2, A.M. Majid, Sejarah Kebudayaan Islam, (Bandung: Pustaka, 1997), 2.

${ }^{3}$ Ibid, 98-99.

${ }^{4}$ Peter. A. Newmark, Textbook of Translation, (UK: Prentice Hall International, 1988), 7.

${ }^{5}$ B.Yunus, Suatu Kajian tentang Teori-Teori Penerjemahan Serta Implikasinya dalam Pengajaran Bahasa. Disertasi FPS IKIP, (IKIP Jakarta, 1989), 2-3.
} 


\section{URGENSI PEMBELAJARAN MENERJEMAH}

ARAB-INDONESIA

perkembangan ilmu pengetahuan dimulai dari penyelenggaraan lembagalembaga penerjemahan yang kemudian menjadi lembaga pendidikan tinggi. ${ }^{6}$

Sedangkan di Indonesia, kegiatan penerjemahan, terutama penerjemahan nas keagamaan, sebagai transfer budaya dan ilmu pengetahuan juga telah dilakukan oleh bangsa Indonesia sejak masa pemerintahan sultan Iskandar Muda (1607-1636 M.) di Aceh. Hal tersebut dibuktikan dengan dijumpainya karya-karya terjemahan ulama Indonesia terdahulu. Upaya umat Islam Indonesia _juga kaum missionaris_ terus berlanjut hingga saat ini. Hal tersebut menggambarkan betapa urgennya kegiatan penerjemahan terhadap perkembangan ilmu pengetahuan dan sabagai sarana pembinaan peradaban umat manusia untuk mencapai suatu kemajuan dan kesejahteraan.

\section{Sekilas Tentang Penerjemahan Arab-Indonesia di Indonesia}

Pada umumnya kegiatan penerjemahan dari bahasa Arab ke bahasa Indonesia terfokus pada nas-nas keagamaan, mulai dari kitab suci al-Qur'an, Hadits, dan Tafsir hingga buku-buku tentang dakwah, akhlak, dan buku-buku yang menelaah aneka pemikiran keislaman.

Kondisi tersebut dapat dimaklumi karena masyarakat Indonesia sangat membutuhkan ilmu agama untuk mengisi, melengkapi, dan menyempurnakan praktik keislaman mereka secara utuh dalam segala dimensinya. Kenyataan ini semakin menguatkan pandangan bahwa penerjemahan yang dilakukan oleh suatu masyarakat hanyalah berkenaan dengan suatu bidang yang tidak dimilikinya, tetapi sangat dibutuhkannya, dan bidang itu dimiliki oleh masyarakat lain serta ditulis dengan bahasa mereka sendiri.

Karena bidang keislaman itu dibutuhkan, maka sebagian orang Islam yang memahami bangsa Arab merasa terpanggil untuk mengkomunikasikan informasi yang terkandung dalam kitab suci dan buku keislaman yang ditulis dalam bahasa Arab melalui kegiatan penerjemahan. Pada awalnya kegiatan tersebut dilakukan secara trial and error hingga akhirnya mereka memperoleh berbagai pengalaman dalam memecahkan persoalan penerjemahan. Kemudian pengalaman tersebut dijadikan prinsip, pedoman, dan acuan dalam melakukan 


\section{URGENSI PEMBELAJARAN MENERJEMAH}

ARAB-INDONESIA

kegiatan selanjutnya. Demikianlah, para penerjemah tersebut umumnya dibesarkan oleh pengalaman individual dan bukan merupakan hasil belajar secara formal.

Hasil terjemahan mereka pada umumnya cukup baik sebagaimana dibuktikan oleh adanya penerbit yang berminat untuk mempublikasikan karya mereka dan adanya para pembaca. Namun, ada beberapa masalah yang sering dihadapi oleh penerjemah Indonesia, di antaranya berkenaan dengan (a) kegiatan penerjemahan itu sendiri yang memang sulit, (b) adanya perbedaan yang substansial antara bahasa Arab dan bahasa Indonesia, (c) kurangnya penguasaan penerjemah terhadap bahasa penerima sehingga menimbulkan gejala interferensi, dan (d) kurangnya penguasaan penerjemah terhadap teori terjemah.

Walaupun terdapat beberapa masalah dalam menerjemah, tetapi di pihak lain terdapat terjemahan nas keagamaan dengan judul Al-Qur'an dan Terjemahannya yang dipandang berkualitas karena beberapa alasan.

Pertama, terjemahan tersebut merupakan hasil karya sekelompok ahli agama Islam, ahli tafsir, dan ahli bahasa Arab yang sudah diakui kepakarannya di tingkat nasional.

Kedua, terjemahan itu dibaca dan dijadikan rujukan oleh berjuta-juta umat Islam dari berbagai kalangan.

Ketiga, terjemahan itu diterbitkan oleh Departemen Agama (Kemenagsekarang) dan beberapa penerbit lain, baik di dalam maupun di luar negeri.

Keempat, penerjemahan dikerjakan selama 8 tahun. Secara teoritis, kedaaan demikian merupakan indikator bahwa terjemahan itu berkualitas.

Kesenjangan seperti itu perlu dimanfaatkan melalui kegiatan empiris. Yakni, perlu dilakukan suatu upaya agar terjemahan yang berkualitas itu berkontribusi terhadap terjemahan yang kurang baik melalui kegiatan penelitian ilmiah. Dari penelitian itu dapat dirumuskan teori-teori menerjemah yang pada akhirnya akan meningkatkan kualitas terjemahan.

\section{Urgensi Pembelajaran Menerjemah Arab-Indonesia}


Ada beberapa alasan mengapa mata kuliah menerjemah perlu diajarkan pada jurusan-jurusan bahasa Arab di perguruan tinggi. Alasan tersebut dapat dikemukakan sebagai berikut.

Pertama, keterampilan menerjemah sangat dibutuhkan dalam rangka alih ilmu pengetahuan, teknologi, kebudayaan, dan agama dari negara maju ke negara-negara berkembang, termasuk Indonesia. Bidang penerjemahan telah memberikan jasanya yang tidak terhingga bagi kemajuan bangsa Arab hingga mereka meraih masa keemasan juga telah membuktikan kesuksesannya dalam mengantarkan bangsa Jepang ke dunia modern yang setara dengan bangsabangsa Barat yang lebih dahulu meraih kemajuan.

Kedua, kegiatan penerjemahan, mulai dari yang sederhana sampai yang kompleks, senantiasa melekat pada diri seseorang yang berkecimpung dalam profesi kebahasaan, baik sebagai guru maupun peneliti. Artinya, penerjemahan merupakan kegiatan alamiah yang perlu dilakukan manusia pada berbagai lapangan kehidupannya, di sekolah, di kantor, dan di mana pun dia berada. Penerjemahan merupakan aktivitas manusia yang bertanggung sepanjang hidupnya.

Ketiga, dewasa ini cukup banyak informasi dari negara-negara asing termasuk negara Arab yang selayaknya dipublikasikan di dalam bahasa Indonesia berupa buku, film, dan publikasi lainnya agar cepat diserap oleh masyarakat. Namun, kegiatan ini belum memperlihatkan hasil yang memuaskan karena keterbatasan tenaga yang profesional dalam bidnag penerjemahan.

Keempat, mata kuliah terjemah berfungsi sebagai sarana pengembang bahasa bagi para mahasiswa di jurusan bahasa Asing termasuk jurusan bahasa Arab. Keterampilan ini dapat menunjang keterampilan berbahasa lainnya, seperti keterampilan berbicara dan menulis. Di samping itu, keterampilan ini pun dapat dijadikan sarana untuk mengetahui keberhasilan studi mahasiswa secara komporehensif, karena keterampilan menerjemah menuntut kemampuan mahasiswa dalam bidang keterampilan berbahasa lainnya, terutama membaca.

Kelima, keterampilan menerjemah dapat dijadikan salah satu nilai tambah bagi seorang lulusan. Dia tidak perlu menggantungkan harapannya 
pada lapangan kerja yang disediakan oleh pemerintah. Keterampilan ini merupakan salah satu alternatif penyediaan lapangan pekerjaan.

Karena alasan-alasan tersebut, kiranya sangat tepat untuk menilik masalah pembelajaran menerjemah dari berbagai sudut pandang.

\section{E. Tujuan Pembelajaran Menerjemah Arab-Indonesia}

Dewasa ini, sedikitnya ada dua bentuk pendidikan penerjemah: Pertama, pendidikan penerjemah yang diselenggarakan dalam bentuk lembaga formal, misalnya sebagai jurusan yang ada di bawah fakultas sastra atau bahasa, sebagai pusat studi terjemah, program pendidikan penerjemah di pascasarjana, program pendidikan diploma, atau dalam bentuk kursus.

Kedua, pendidikan penerjemah yang diwujudkan dalam bentuk mata kuliah terjemah dan diselenggarakan oleh berbagai jurusan pendidikan bahasa asing yang ada di bawah fakultas sastra atau bahasa. Pada umumnya pendidikan penerjemahan yang demikian disajikan dalam dua mata kuliah, yaitu penerjemahan dari bahasa sumber ke bahasa penerima dan penerjemahan dari bahasa penerima ke bahasa sumber. Jumlah SKS setiap mata kuliah ini berkisar antara 2 dan 3 SKS.

Tentu saja tujuan pendidikan penerjemahan perlu dirumuskan sesuai dengan bentuknya masing-masing. Rumusan tujuan pendidikan penerjemahan sebagai sebuah lembaga pendidikan berbeda dengan pendidikan penerjemahan yang disajikan sebagai sebuah mata kuliah.

Namun, secara substansial pembelajaran menerjemah pada kedua bentuk pendidikan itu bertujuan mendidik pembelajar agar memiliki kompetensi disimilatif, yaitu kemampuan membandingkan dan mengolah dua sistem bahasa dan budaya yang berbeda. ${ }^{7}$

Adapun secara operasional, pendidikan atau pembelajaran ini memiliki dua tujuan utama, yaitu membekali mahasiswa dengan pengetahuan tentang teori menerjemah dan membekali mahasiswa dengan pengalaman dalam menerjemahkan berbagai jenis nas, seperti nas agama, keilmuan, sastra, ekonomi, dan budaya dengan berbagai tingkat kesulitannya. Ringkasnya, kedua

\footnotetext{
${ }^{7}$ L. Hewson, and J. Martin, Redefining Translation: the Variational Approach, (London: Rouledge, 1991), 211.
} 
bentuk lembaga ini bertujuan membina mahasiswa dengan teori dan praktik penerjemahan.

Tujuan pendidikan penerjemahan yang berbentuk lembaga adalah membina calon-calon penerjemah profesional. Pada umumnya tujuan demikian dirumuskan oleh lembaga pendidikan jenjang S-2, spesialisasi, dan jenjang S-1. Kiranya, profesionalisme penerjemah sulit diraih melalui pendidikan yang berbentuk program diploma tiga (D-3) atau kursus-kursus, karena keterampilan menerjemah membutuhkan berbagai pengetahuan yang sulit diraih dalam waktu yang relatif singkat. Dalam penerjemahan terdapat keterampilan, seni, krativitas, dan intuisi yang tidak dapat diraih melalui bangku kuliah, tetapi hanya diraih melalui pengalaman dan praktik langsung di lapangan yang sesungguhnya.

Kemampuan-kemampuan tersebut dapat dikembangkan melalui beberapa tujuan perkuliahan, yaitu: Memahami dan menguasai sepenuhnya bahasa Indonesia pada tingkat reseptif maupun produktif; Memiliki kemampuan reseptif dalam bahasa sumber yang mendekati penutur asli; Mengetahui dan memahami kebudayaan Indonesia; Mengetahui dan memahami kebudayaan penutur bahasa sumber; Mengetahui garis besar berbagai bidang ilmu pengetahuan; Menguasai teori terjemah, dan Memiliki keluwesan kognitif dan keluwesan sosial budaya. ${ }^{8}$

Adapun pendidikan penerjemahan yang disajikan dalam bentuk mata kuliah bertujuan membina mahasiwa dalam keterampilan dasar menerjemah sehingga mata kuliah ini dapat membantu mahassiwa dalam mendalami mata kuliah lain yang relevan. Karena itu, sifat mata kuliah ini bersifat pelengkap dan penunjang bagi mata kuliah lain.

Melalui mata kulia tersebut, mahasiswa diharapkan memiliki keterampilan menerjemah pada tingkat permulaan, yaitu kemampuan mengungkapkan makna dan maksud nas sumber di dqlaam nas penerima dengan benar dan jelas. Pada tingkat ini mahasiswa tidak dituntut untuk menghasilkan terjemahan yang wajar dengan tingkat kecepatan yang relatif tinggi.

\footnotetext{
${ }^{8}$ Z. Suryawinata, Analisis dan Evaluasi terhadap Terjemahan Novel Sastra The Adventures Of Huckleberry Finn dari bahasa Inggris ke Bahasa Indonesia. Disertasi FPS IKIP, (IKIP Malang, 1982), 50.
} 
Demikianlah tujuan pendidikan penerjemahan dengan kedua bentuknya yang berbeda. Perbedaan bentuk dan tujuan ini berimplikasi pada perbedaan bahan ajar, metode pembelajaran, dan evaluasi pembelajaran, sehingga tiaptiap bentuk menuntut pembahasan tersendiri. Namun, uraian berikut tidak akan membahas keduanya secara rinci, tetapi secara umum saja supaya dapat memenuhi berbagai pihak yang terlibat dalam kedua bentuk tersebut.

\section{F. Bahan Ajar Pembelajaran Menerjemah Arab-Indonesia}

Secara umum, materi pelajaran menerjemah terbagi dua: teori dan praktik. ${ }^{9}$ Bahan ajar teoritis meliputi bahasa sumber dan bahasa sing, teori terjemah, kebudayaan penutur bahasa sumber dan penerima, pengetahuan umum, dan hal-hal tentang penerbitan.

Materi praktik meliputi praktik penerjemahan berbagai jenis nas, praktik analisis struktur kalimat yang kompleks, operasionalisasi metode dan prosedur penerjemahan melalui berbagai jenis wacana, penerjemahan kosa kata kebudayaan, dan pemecahan masalah-masalah yang lazim dijumpai dalam praktik penerjemahan.

Perkembangan teknologi informasi, khususnya komputer, pada akhirakhir ini sungguh sangat pesat. Perkembangan ini berdampak positif pula pada bidang penerjemahan. Penerjemah memperoleh berbagai kemudahan dari berbagai program yang ada, terutama penerjemah buku-buku keagamaan dari bahasa Arab ke bahasa Indonesia. Penerjemahan buku agama Islam biasanya dituntut untuk menyajikan nas sumber, khususnya nas Al-quran dan Sunnah. Tuntutan ini dapat dipenuhi dengan mudah oleh program-program keislaman. Kondisi demikian menuntut diajarkannya keterampilan penggunaan program komputer tertentu kepada penerjemah.

Materi praktik penerjemahan perlu didasarkan pada nas otentik, bukan nas yang direkayasa dan dipersiapkan oleh dosen sebagai bahan perkuliahan. Bahan demikian biasanya kaya akan ragam dan gaya bahasa serta mencakup berbagai problematika penerjemahan yang realistis. Hal ini dapat membekali

\footnotetext{
${ }^{9}$ L. Leaderer, and D. Seleskovitch, Menginterpretasi Untuk Menerjemahkan. (Penerjemah: Rahayu S. Hidayat dan Edlin H. Eddin), (Jakarta: Pusat Pembinaan dan Pengembangan Bahasa, 1986).
} 
penerjemah dengan pengalaman nyata yang kelak akan berguna tatkala dia berhadapan dengan nas yang sesungguhnya.

Nas otentik tersebut perlu disesuaikan dengan materi teori. Dengan perkataan lain, materi praktik dimaksudkan untuk mengasah dan mengaplikasikan materi teori. Sebagai contoh, materi tentang konsep penerjemahan dapat dipertajam dengan meminta mahasiswa menerjemahkan nas-nas yang benar-benar tidak dapat diterjemahkan secara harfiah, tetapi mesti diungkapkan maknanya. Berikut ini adalah contoh kecil materi yang otentik.

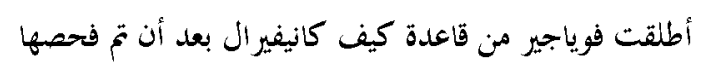

Dalam menerjemahkan kalimat di atas, penerjemah dituntut untuk mengungkapkan maknanya secara komunikatif. Kata uthliqat dapat berarti dilepaskan, digunakan, dibebaskan, dan seterusnya. Namun, terjemahan demikian tidaklah komunikatif bagi pembaca di Indonesia. Demikian pula kata qa'idah tentu tidak cocok dengan konteks di atas. Kalimat di atas kiranya dapat diterjemahkan dengan Voyager diluncurkan dari anjungan Cape Caneveral setelah selesai diteliti.

\section{G. Metode Pembelajaran Menerjemah Arab-Indonesia}

Perancanangan metode pembelajaran menerjemah dapat dilakukan selaras dengan cakupan materi perkuliahan menerjemah yang meliputi aspek teoritis dan praktis. Pembelajaran aspek teori perlu dirumuskan dengan mempertimbangkan hakikat penerjemahan, tujuan pembelajaran terjemah, dan bentuk pembelajarannya.

Telah dijelaskan pada bab sebelumnya, bahwa pada hakikatnya kegiatan menerjemah berkaitan dengan pencarian ekuivalensi antara bahasa sumber dan bahasa penerima. Karena itu, mahasiswa yang mengambil mata kuliah menerjemah harus ditekankan pada penguasaan aspek-aspek persamaan dan pebedaan antara bahasa sumber dan bahasa penerima.

Jenis-jenis pola kalimat, variasi klausa, keragaman frase, dan sistem ejaan merupakan bahan ajar yang harus dijadikan perhatian. Di samping itu 
perlu disampaikan pula ekuivalensi budaya antara bahasa sumber dan bahasa penerima melalui peribahasa, ungkapan, dan struktur idiomatis.

Pembelajaran demikian diharapkan dapat mengurangi gejala interferensi pada terjemahan. Jika mahasiswa sudah menguasai aspek ini, maka tahap selanjutnya adalah pembelajaran tentang pemakaian istilah, ungkapan dan kolokasi serta kewajaran nas.

Pokok bahasan pertama adalah kosa kata. Penelitian yang dilakukan oleh Syihabuddin ${ }^{10}$ menunjukkan betapa pentingnya penguasaan penerjemah terhadap makna inti suatu kata, komponen-komponen semantis, persamaan dan perbedaan kosa kata yang serumpun, dan konteks pemakaiannya. Karena itu, kosa kata dapat diajarkan melalui beberapa metode seperti berikut.

Pertama, dengan memperbandingkan kelompok kata yang serumpun sebagaimana dikemukakan oleh Larson. ${ }^{11}$ Dia mengkontraskan kelompok kata yang memiliki kesamaan. Kosa kata dikelompokkan ke dalam satu kategori. Kemudian ditelaah ciri-ciri persamaan dan perbedaan makna antara dua kata yang dikontraskan itu. Ciri-ciri itu berupa komponen-komponen makna sehingga diketahuilah konsep utama dari tiap-tiap kata yang dibandingkan.

Kedua, malalui konteks. Kebaikan cara ini dikuatkan oleh Fisher (1994) yang melakukan eksperimen tentang pembelajaran kosa kata. Dia membandingkan pembelajaran kosa kata melalui konteks dan melalui kamus. Dia menyimpulkan bahwa belajar kosa kata baru melalui konteks lebih efektif daripada melalui kamus.

Pokok bahasan kedua adalah teori terjemah dam problematika penerjemahan. Pokok bahasan ini berkenaan dengan metode, prosedur, dan teknik penerjemahan yang dapat mengkompromikan perbedaan dan persamaan antara bahasa Arab dan bahasa Indonesia. Bahan ini dapt disampaikan dengan metode ceramah, diskusi, dan tanya jawab. Di samping itu, yang paling penting adalah bahwa teori terjemah harus disampaikan dengan

10 Syihabuddin. Prosedur Penerjemahan Nas Keagamaan dan Keterpahamannya: Telaah Ihwal Teknik, Kualitas Terjemahan, Hukum, dan Pengajarannya, (Bandung: Disertasi, Universitas Pendidikan Indonesia, 2000).

${ }^{11}$ ML. Larson, Meaning-Based Translation: a Guide to Crass-Language Equivalence, (Boston: University Press of America, 1984), 79-80. 
mendemonstrasikannya dalam menyelesaikan kasus-kasus penerjemahan secara langsung melalui praktik.

Pokok bahasan ketiga adalah praktik penerjemahan. Sebaiknya pokok materi ini dilakukan melalui kelompok-kelompok yang dipimpin oleh mahasiswa yang memiliki kemampuan yang melebihi teman-temannya. Praktik difokuskan pada penerapan sebuah teori untuk jenis nas tertentu. Selanjutnya hasil pekerjaan kelompok dilaporkan di depan kelas. Dosen dan kelompok dapat meluruskan, mengkritik, menyarankan, dan memperbaiki hasil kelompok penyaji.

Diharapkan melalui cara ini terjadilah interaksi belajar yang intensif di anatara parta mahasiswa. Hal-hal yang enggan untuk ditanyakan kepada dosen akan dikemukakan kepada temannya dengan leluasa.

Demikianlah bahan ajar dapat disampaikan dengan mempertimbangkan karakteristik materi dan tingkat pendidikan. Bahan tentang perbedaan antara bahasa sumber dan penerima dapat disampaikan dengan metode kontrastif, sedangkan masalah kosa kata dapat dilakukan dengan metode analisis kompnen. Adapun dalam praktik penerjemahan dapat dilakukan dengan metode pembelajaran sebaya. Menurut pengalaman, metode ketiga ini cukup berhasil diterapkan pada mahasiswa pada tingkat lanjut.

\section{H. Dosen Terjemah}

Dalam bidang penerjemahan, hubungan antara teori dan praktek tidak dapat dipisahkan. Teori terjemah dirumuskan dari praktik penerjemahan. Tidak ada praktik berarti tidak ada teori. Pada gilirannya, teori juga memberikan arah pada praktik penerjemahan. Kedua bidang ini berjalan secara simultan, saling melengkapi, dan mengembangkan.

Karena itu, dosen yang mengampu mata kuliah menerjemah hendaknya memiliki pengalaman menerjemah yang memadai. Dosen yang mengajar mata kuliah kebudayaan Arab sebagai bagian dari mata kulia di jurusan terjemah dituntut untuk mampu mengaplikasikan perbedaan kebudayaan yang tercermin pada bahasa sumber dan bahasa penerima. Artinya, dosen mata 
kuliah ini harus mampu mendemonstrasikan cara mengatasi perbedaan kebudayaan dan terdapat pada nas yang diterjemahkan.

Sebuah fenomena yang cukup mengkhawatirkan dalam bidang penerjemahan Arab-Indonesia adalah adanya kesan seolah-olah bahasa Indonesia itu tidak perlu diajarkan, padahal mengajarkan terjemah berarti mengajar dua bahasa sekaligus

Dosen terjemah dituntut untuk memiliki kualifikasi teoritis, pengalaman, dan menguasai bahas sumber dan bahasa penerima dengan tingkat sama baiknya serta menguasai kebudayaan kedua bahasa itu.

\section{Evaluasi Pembelajaran Menerjemah Arab-Indonesia}

Yang dimaksud evaluasi di sini adalah pengukuran kemampuan mahasiswa dalam menguasai masalah-masalah penerjemahan. Evaluasi terhadap kemampuan menerjemah tentu harus dilakukan melalui terjemahan. Kuranglah tepat jika kemampuan itu diukur melalui pengetahuan teoritis belaka.

Beberapa ahli seperti Larson, ${ }^{12}$ dan Nida, ${ }^{13}$, fokus evaluasi terjemahan adalah ketepatan dan kejelasan terjemah. Ini berarti bahwa mahasiswa yang berkemampuan baik adalah yang dapat menerjemah nas sumber dengan benar dan jelas.

Bahan evaluasi yang diberikan berupa unit-unit terjemah yang merentang mulai dari ungkapan lengkap, kalimat, dan wacana yang utuh. Penilaian ketepatan didasarkan atas kesesuaian terjemahan dengan ide pokok atau amanat bahasa sumber yang telah dipersiapkan sebelumnya, sedangkan penilaian kejelasan terjemahan didasarkan atas kerumitan atau kesederhanaan struktur kalimat, ketepatan pemakaian ejaan, dan pemilihan kosa kata.

Butir-butir tes yang disiapkan mesti mengukur apa yang seharusnya diukur. Artinya tes itu sahih. Kesahiihan sebuah tes menyangkut kesahihan isi, kesahihan kriteria, dan kesahihan lahiriyah atau konstruksi. Tes terjemahan itu dikatakan sahih isinya, jika dapat mencerminkan contoh keterampilan

\footnotetext{
${ }^{12}$ ML. Larson, Meaning-Based Translation: a Guide to Crass-Language Equivalence, 80.

${ }^{13}$ E.A Nida, and C. Taber, The Theory and Practise of Translation, (Leiden: The United Bible Societies, 1982).
} 
berbahasa yang menjadi fokus tes itu. Artinya, item tes itu mengandung suatu pengetahuan, pemnahaman, atau keterampilan yang hendak diukur.

Di samping sahih, tes menerjemah pun harus memiliki keandalan, yaitu menunjukkan derajat keajegan hasil pengukuran prestasi belajar yang terwujud dalam bentuk skor. Skor itu relatif stabil walaupun instrumen yang digunakannya berbeda, waktu pelaksanannya berbeda, dan metode pengukurannya juga berbeda. Evaluasi pembelajaran juga menyangkut kinerja dosen. Aspek-aspek kinerja yang perlu diperhatikan adalah masalah penyiapan Satuan Acara Perkuliahan (SAP) atau Rencana Perkulaihan Semester (RPS), metode mengajar dengan berbagai unsurnya, dan kompetensi akademiknya.

\section{J. Kesimpulan}

Proses berkembangnya kebudayaan dapat terjadi melalui sarana penerjemahan. Dalam catatan sejarah ditegaskan bahwa peradaban Islam pada awalnya berkembang melalui penerjemahan karya-karya lama Yunani, Persia, India, dan Mesir dalam bidang ilmu eksakta dan kedokteran.

Kegiatan penerjemahan ini dimulai pada masa pemerintahan Khalifah Abu Ja'far al-Mansur, salah satu khalifah dari Dinasti Abbasiah. Upaya penerjemahan yang dimulai oleh khalifah Abu Ja'far tersebut berhasil dan mencapai puncaknya pada masa Khalifah al-Ma'mun sehingga mengantarkan umat Islam ke masa keemasan.

Kemajuan bangsa dapat diraih melalui kegiatan penerjemahan, seperti halnya bangsa Jepang. Pesatnya perkembangan ilmu pengetahuan dimulai dari penyelenggaraan lembaga-lembaga penerjemahan yang kemudian menjadi lembaga pendidikan tinggi atau jurusan atau program studi pada perguruan tinggi.

Adapun di Indonesia, pada umumnya kegiatan penerjemahan dari bahasa Arab ke bahasa Indonesia terfokus pada nas-nas keagamaan, mulai dari kitab suci al-Qur'an, Hadits, dan Tafsir hingga buku-buku tentang dakwah, akhlak, dan buku-buku yang menelaah aneka pemikiran keislaman.

Hasil terjemahan mereka pada umumnya cukup baik sebagaimana dibuktikan oleh adanya penerbit yang berminat untuk mempublikasikan karya 
mereka dan adanya para pembaca. Namun, ada beberapa masalah yang sering dihadapi oleh penerjemah Indonesia, di antaranya berkenaan dengan (a) kegiatan penerjemahan itu sendiri yang memang sulit, (b) adanya perbedaan yang substansial antara bahasa Arab dan bahasa Indonesia, (c) kurangnya penguasaan penerjemah terhadap bahasa penerima sehingga menimbulkan gejala interferensi, dan (d) kurangnya penguasaan penerjemah terhadap teori terjemah. Untuk itu, mata kuliah menerjemah perlu diajarkan pada jurusanjurusan bahasa Arab di perguruan tinggi Islam di Indonesia.

Di Indonesia, ada dua bentuk pendidikan penerjemah: Pertama, pendidikan penerjemah yang diselenggarakan dalam bentuk lembaga formal, misalnya sebagai jurusan yang ada di bawah fakultas sastra atau bahasa, sebagai pusat studi terjemah. 


\section{DAFTAR PUSTAKA}

Hewson, L. and Martin, J. Redefining Translation: the Variational Approach. (London: Rouledge, 1991)

Larson, M.L. Meaning-Based Translation: a Guide to Crass-Language Equivalence. (Boston: University Press of America, 1984)

Leaderer, L. and Seleskovitch, D. Menginterpretasi Untuk Menerjemahkan. (Penerjemah: Rahayu S. Hidayat dan Edlin H. Eddin). (Jakarta: Pusat Pembinaan dan Pengembangan Bahasa, 1986)

Majid, A.M. Sejarah Kebudayaan Islam. (Bandung: Pustaka, 1997).

Mufid, Nur. Buku Pintar Menerjemah. (Surabaya: Pustaka Progresif, 2007)

Newmark, Peter. A Textbook of Translation.(UK: Prentice Hall International, 1988)

Nida, E.A and Taber, C. The Theory and Practise of Translation. (Leiden: The United Bible Societies, 1982)

Suryawinata, Z. Analisis dan Evaluasi terhadap Terjemahan Novel Sastra The Adventures Of Huckleberry Finn dari bahasa Inggris ke Bahasa Indonesia. Disertasi FPS IKIP, IKIP Malang, 1982.

Syihabuddin. Prosedur Penerjemahan Nas Keagamaan dan Keterpahamannya: Telaah Ihwal Teknik, Kualitas Terjemahan, Hukum, dan Pengajarannya. (Bandung: Disertasi, Universitas Pendidikan Indonesia, 2000)

Yunus, B. Suatu Kajian tentang Teori-Teori Penerjemahan Serta Implikasinya dalam Pengajaran Bahasa. Disertasi FPS IKIP, IKIP Jakarta, 1989. 